\title{
曲り旋回流におけるオリフィス背後の流れと物質輸送に及ぼす旋回強度の影響 Influence of Swirl Intensity on Flow and Mass Transfer behind an Orifice in Curved Swirling Flow
}

\author{
$\bigcirc$ 金谷 信明（新潟大）高野 剛（新潟大） 正 山縣 貴幸（新潟大） \\ 西宮 紹（新潟大） 内山 和哉（新潟大）正 藤澤 延行（新潟大）
Nobuaki KANATANI, Niigata University, 8050, 2notyou, Ikarashi, Niigata Niigata
Tsuyoshi TAKANO, Niigata University, 8050, 2notyou, Ikarashi, Niigata Niigata
Takayuki YAMAGATA, Niigata University, 8050, 2notyou, Ikarashi, Niigata Niigata
Shou NISHIMIYA, Niigata University, 8050, 2notyou, Ikarashi, Niigata Niigata
Kazuya UTIYAMA, Niigata University, 8050, 2notyou, Ikarashi, Niigata Niigata
Nobuyuki FUJISAWA, Niigata University, 8050, 2notyou, Ikarashi, Niigata Niigata

Key Words: Flow Accelerated Corrosion, Orifice, Pipe-wall Thinning, Mass Transfer, Swirling Flow, Curved Flow, Stereo PIV,

\section{1. 緒言}

発電プラントの各種配管における配管減肉の発生メカニ ズムの解明と高精度予測技術の確立は，プラントの危機管 理や安全運転において重要な課題である。配管減肉の発生 原因の一つに流れ加速型腐食がある。これは配管材料の鉄 イオンが作動流体中に溶解する拡散現象が流動によって加 速される現象であり，一般に物質輸送現象として捉えられ ている.

流れ加速型腐食による配管減肉が原因とされる代表的な 事例として 2004 年に起きた美浜原子力発電所の配管破断 がある。この事例では，オリフィス下流に非軸対称な配管 減肉が発生し, 局所的に配管減肉が進行したため, 配管破 断に至ったと考えられている(1). 最近の研究によると, こ のような非軸対称な減肉現象の発生メカニズムの一つとし て, 旋回流とオリフィス偏心の組み合わせ効果によって発 生した非軸対称流が関係すると考えられている.すなわち, JIS 規格内での僅かなオリフィスの偏心（配管外径の \pm 0 . 8\%）においても，旋回流を伴う場合には，オリフィス流の 不安定により非軸対称流となることが知られている(2), (3). また，オリフィス上流側に設置されたエルボなどの曲り部 と旋回流の組み合わせ効果が, オリフィス偏心以上にオリ フィス背後の非軸対称流の発生に影響することがわかって いる(4),(5).

本研究では，上流に曲り管を有するオリフィス流におい て, 旋回流強度とオリフィス背後の非軸対称流の関係を明 らかにし, 非軸対称な配管減肉の発生条件を明らかにする.

\section{2. 実験装置および方法}

\section{$2 \cdot 1$ 実験装置}

実験装置は，ポンプ，整流部，測定部から構成される回 流水槽であり，作動流体には水を用いた。.Fig. 1 は曲り部 及び測定部の模式図である。整流部の背後に旋回流を発生 するためのスワーラ, その下流側 7D（D: 管内径）の位置 にロングエルボが設置されている. 曲り部下流に $10 D$ の直 管部を介して，オリフィスならびに測定部が接続されてい る. 管内径は $D=56 \mathrm{~mm}$, オリフィス絞り比は 0.6 (内径 $33.6 \mathrm{~mm}$ ) である. 実験は, 流速 $U_{0}=0.5 \mathrm{~m} / \mathrm{s}$ で行い, レイ ノルズ数は Re $=3 \times 10^{4}$ である. スワーラは内部に八ニカ ムを有する円管をモータで回転させる構造であり, インバ ータによってモータの回転を制御し旋回強度を変化させた. 旋回流の評価として, 軸方向運動量及び周方向運動量の比 であるスワール数を用いた ${ }^{(3)}$. 実機配管の再現実験で得ら
れた旋回流強度の值は, オリフィス前 $3.0 D$ の位置では, $S w$ $=0.26^{(3)}$ であった.

\section{$2 \cdot 2$ ステレオ PIV 計測}

本実験で用いた PIV システムは，Nd:YAG パルスレーザ (波長 $\lambda=523 \mathrm{~nm}, 50 \mathrm{~mJ} / \mathrm{pulse}$ ), モノクロ CCD カメラ (1008 × 1018 pixels, 8 bits），パルスジェネレータで構成される. 流れの可視化には, 直径 $40 \mu \mathrm{m}$ のナイロン粒子 (比重 1.02) を用いた。粒子の移動量計算のアルゴリズムには, 直接相 互相関法にサブピクセル解析を組み合わせて用いた。

ステレオ PIV 計測では, Fig. 1 に示すように, 2 台のカメ ラを管軸に対してそれぞれ 450傾斜させ，レンズはシャイ ンプルーフ条件を満足するように設置した。また，レーザ シート光は, 管上方から照射した. カメラ画像の校正は, 検定板を測定部下流側から挿入し，検定板を奥行き方向に $0.5 \mathrm{~mm}$ 間隔で 5 断面撮影し, 格子点画像を 3 次スプライン 近似することで行った。 また, 疑似粒子画像を用いてステ レオ PIVによる計測誤差を評価したところ, 左右のカメラ

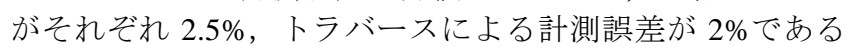
ため, 本ステレオ PIV の計測誤差は 4\%である.

\section{$2 \cdot 3$ 旋回中心の可視化実験}

曲り管およびオリフィスを通過する旋回流の挙動を観察 するため, 気泡トレーサを用いて旋回中心の可視化行った. スワーラの $4 D$ 後方から注入器を用いて直径約 $1.5 \mathrm{~mm}$ の気 泡を管内に挿入した。この時，気泡は旋回流の遠心力の影 響で旋回中心を流れる。気泡の挙動は, 直交する 2 台の力 メラを用いてシャドーグラフ法により計測した． 2 台のカ メラで得られた気泡の位置から, 気泡の 3 次元位置を算出 した.

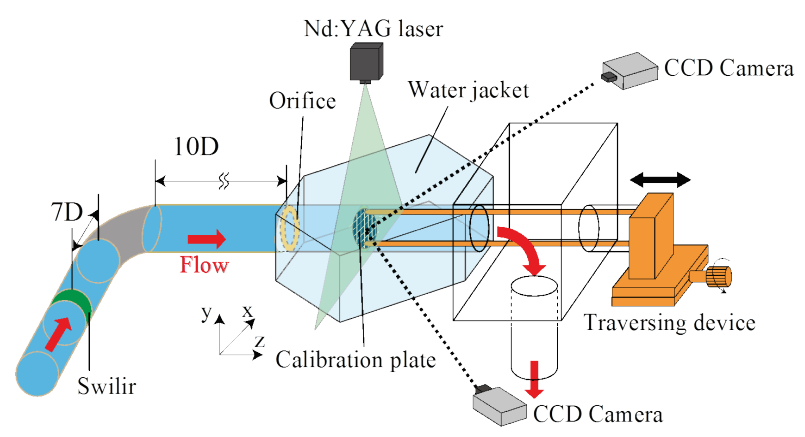

Fig. 1 Experimental setup 


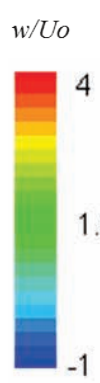

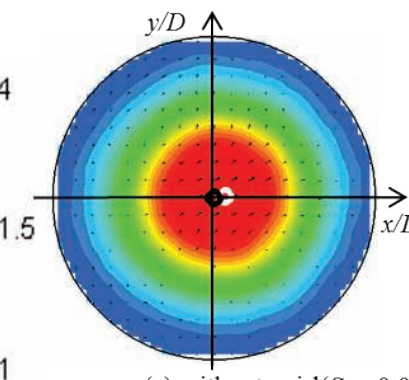

(a) without $\operatorname{swirl}(S w:-0.04)$

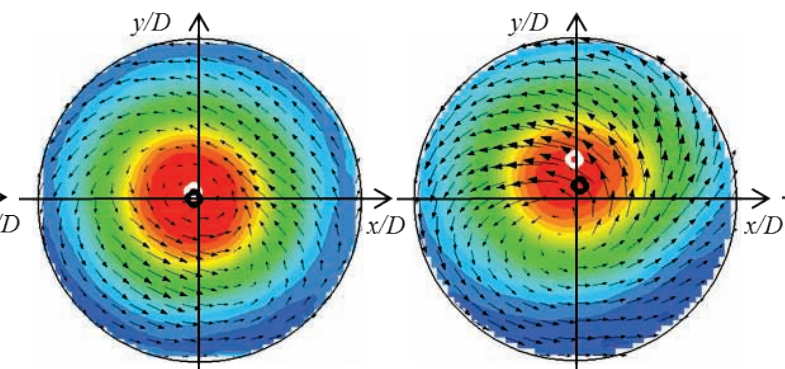

(c) with $\operatorname{swirl}(S w: 0.26)$

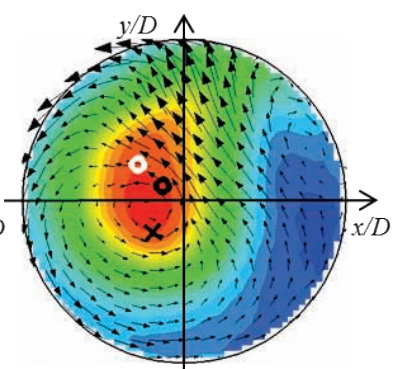

(d) with $\operatorname{swirl}(S w: 0.30)$

Fig. 2 Mean velocity fields behind an orifice with centers of momentum ( $\circ$ : axial velocity, $\bullet$ : circumferential velocity, $\times$ : swirl center from bubble experiment)

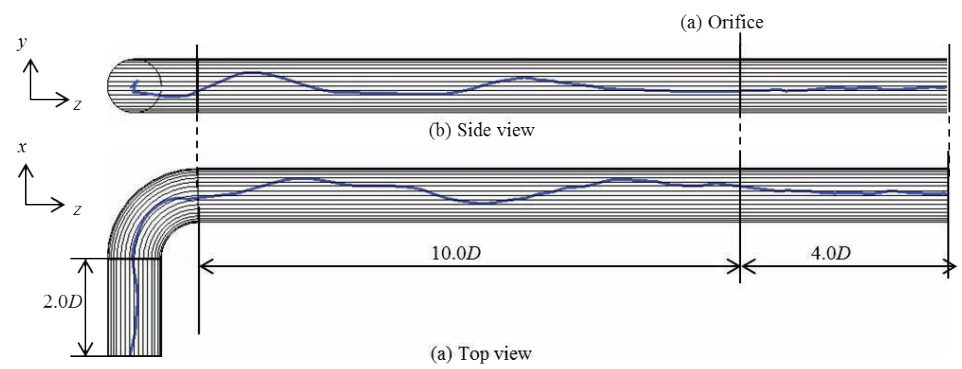

Fig. 3 Three dimensional behavior of swirl center from bubble experiment ( $S w=0.3$ ): (a) $y$-z plane; (b) $x$-z plane

\section{3. 実験結果および考察}

Fig. 2 はオリフィス下流 $1 D$ におけるステレオPIV 計測に より得られた速度分布で，それぞれ旋回無(a)および強度の 異なる旋回流 $S w=0.2$ (b), 0.26 (c), 0.3 (d) の結果である. ただし，旋回強度のスワール数は，オリフィス上流 $3 D$ で 評価した。図中の白点，黒点はそれぞれ軸方向および周方 向運動量の中心を示している．旋回無の場合(a)では，軸対 称な速度場が形成されており，運動量の中心もほぼ管中心 に位置している。この結果は，直管におけるオリフィス背 後の結果 ${ }^{(3)}$ と同様であり, 旋回無の場合, オリフィス上流 10Dの位置に設置された曲がり部の影響を受けないことが 確認できる，弱い旋回流(b)では，オリフィス背後でも旋回 流の影響は見られるが, 速度分布は軸対称性を保っており, 運動量中心も管中心とほぼ一致している，次に，旋回流強 度を増した場合(c)では, 流れが僅かに上方に偏っている. また，運動量中心も上方に移動している．さらに旋回流強 度を増した場合(d)では，他の旋回流に比べて速度分布に強 い非軸対称性が現れている。さらに，気泡の可視化実験よ り得られた旋回中心を $\times$ 印で示している.PIVで得られた 軸方向運動量の中心と可視化実験の結果は，ばらつきの範 囲内で一致している。また，管右上では逆向きの二つの渦 が確認でき, 複雑な流れになっている.これらの結果より 曲り部を通過した旋回流は, 旋回強度が増すとオリフィス 背後に非軸対称な流れを形成することが明らかとなった. 気泡による旋回中心の可視化実験で得られた気泡の 3 次元 挙動の計測結果を Fig. 3 に示す. それぞれ，曲り部の水平 断面(a)および垂直断面(b)での計測結果であり, 旋回強度が 最も大きい $S w=0.3$ の場合である. 曲り部を通過後, 旋回 中心はうねりのような挙動を示しており，旋回流と曲り部 の組み合わせにより非軸対称な流れが形成されている。こ の非軸対称な流れが，オリフィスを通過することでオリフ イス流の不安定性を増大させ，オリフィス背後に強い偏流 を生じると考えられる。

Fig. 4 は, オリフィス背後における運動量の中心位置 $r_{m}$ と旋回強度の関係を示す. 軸方向および周方向運動量とも に旋回強度が $S w=0.2$ 程度までは, 運動量中心はほぼ管中

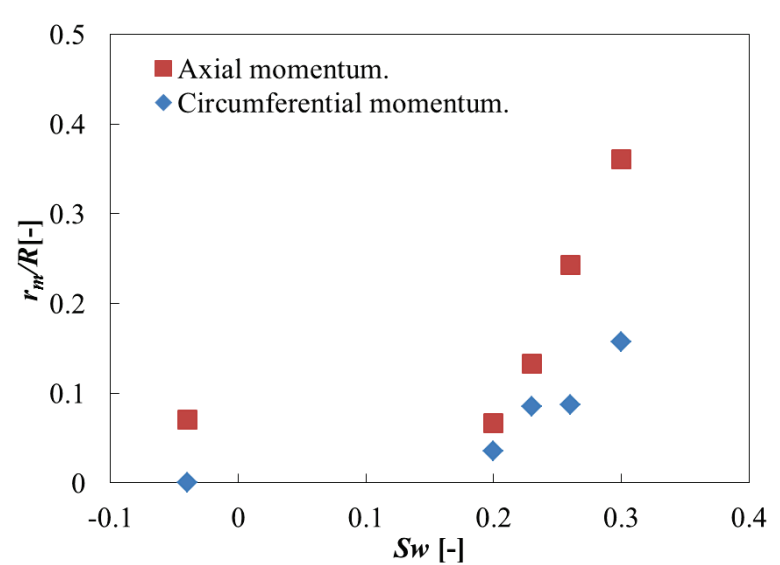

Fig. 4 Center of momentum versus swirl intensity

心にあり，軸対称な流れを保っている。さらに旋回強度を 増加すると，運動量中心のずれも増加している.このこと から，オリフィス背後に強い非軸対称な流れを生じさせな いためには，旋回流強度を $S w=0.2$ 以下にすることが望ま しいと考えられる。

\section{4. 結言}

本研究では，曲り管とオリフィスを有する配管系統にお いて，旋回流強度とオリフィス背後の非軸対称流の関係を ステレオ PIVによって実験的に検討した．その結果，旋回 強度が一定の值を超えると, オリフィス背後に非軸対称な 流れが生じることが明らかとなった。

\section{参考文献}

(1) 経済産業省, http://www.meti.go.jp/commitee/materials/g 41213aj.html, 資料 7-1-1, (2004)

(2) Ohkubo, M. et al., J. Vis., 14 (2011), 15-17.

(3) 大久保, 他 3 名, 機論 B 編, 77 (2011), 386-394.

(4) 金谷, 他 2 名, 保全学会第 9 回学術講演会 (2012), 179-182.

(5) Takano, T. et al., J. Flow Contr. Meas Vis, 1-1(2013), 1-5. 